\title{
Applied Geography: Principles and Praxis
}

\author{
Michael Pacione
}

\begin{abstract}
An applied geographical approach has the potential to illuminate the nature and causes of a wide range of economic, social and environmental problems, and inform the formulation of appropriate responses. This paper provides an overview of the principles and praxis of applied geography. First we examine the conceptual foundations of applied geography and consider the relationship between pure and applied research, and the concept of useful knowledge. This conceptual discussion is then complemented by empirical case study examples of applied research in the field of urban geography, with particular reference to the key question of quality of life and human wellbeing. Finally, we adopt a prospective perspective to address the question of the value of applied geography in contemporary society.
\end{abstract}

Key words: applied geography, urban geography, quality of life

\section{Primijenjena geografija: načela i primjena}

Pristup primijenjene geografije ima mogućnost razjasniti uzroke velikog broja ekonomskih, socijalnih i ekoloških problema, te stvoriti osnovu za njihovo rješavanje. U članku se daje sažeti pregled načela primijenjene geografije te se raspravlja o mogućnostima njene primjene u praksi. Prvi dio rada odnosi se na konceptualnu utemeljenost primijenjene geografije. Također se raspravlja o odnosu između teorijskog i primijenjenog istraživanja, a definiran je i pojam korisnoga znanja. U drugom je dijelu rada prikazana mogućnost primjene geografskog znanja u području urbane geografije. Posebna pažnja posvećena je pitanjima kvalitete života i ljudskog blagostanja. Završno je prikazano značenje primijenjene geografije u suvremenom društvu.

Ključne riječi: primijenjena geografija, urbana geografija, kvaliteta života

\section{INTRODUCTION}

The relevance and value of applied geographical research has never been more apparent given the plethora of problem situations which confront modern societies - ranging from extreme natural events (such as floods, drought and earthquakes) through environmental concerns (such as deforestation, disease and desertification) to human issues (such as crime, poverty and unemployment) (Tab. 1). An applied geographical approach has the 
potential to illuminate the nature and causes of such problems and inform the formulation of appropriate responses.

Tab. 1 Examples of contemporary research issues in applied geography

Tab. 1. Primjeri suvremene problematike istraživanja u primijenjenoj geografiji

\begin{tabular}{|c|c|}
\hline $\begin{array}{l}\text { NATURAL AND ENVIRONMENTAL } \\
\text { HAZARDS }\end{array}$ & TECHNIQUES OF SPATIAL ANALYSIS \\
\hline Global Warming & Remote Sensing and Environmental Change \\
\hline Acid Precipitation & Computer Cartography \\
\hline Extreme Weather Events & Geodemographics \\
\hline Earthquakes and Vulcanism & Global Positioning Systems \\
\hline Landslides & Computer Simulation \\
\hline Floods & Modelling Urban Structure \\
\hline Coastal Erosion & Geographic Information Systems \\
\hline \multicolumn{2}{|l|}{ Physical Problems of Urban Environments } \\
\hline $\begin{array}{c}\text { ENVIRONMENTAL CHANGE AND } \\
\text { MANAGEMENT }\end{array}$ & $\begin{array}{l}\text { CHALLENGES OF THE HUMAN } \\
\text { ENVIRONMENT }\end{array}$ \\
\hline Water Supply and Management & Urbanization and Counterurbanization \\
\hline Water Quality and Pollution & Boundary Disputes \\
\hline Irrigation & $\begin{array}{l}\text { Political Spaces and Representation Within } \\
\text { States }\end{array}$ \\
\hline Desertification & Housing Problems in the Developed World \\
\hline Deforestation & The Geography of Poverty \\
\hline Maintaining Biodiversity & Segregation and Discrimination \\
\hline Landscape Evaluation & Socio-spatial Variations in Health \\
\hline Environmental Impact Assessment & Crime and Fear of Crime \\
\hline Countryside Recreation Management & Retail Location Analysis \\
\hline Deintensification of Agriculture & Urban Transport and Traffic \\
\hline Wetlands Conservation & Rural Accessibility \\
\hline Land Use Conflict & City Marketing \\
\hline Derelict and Vacant Land & Low Income Shelter in the Third World \\
\hline Sustainable Tourism & Informal Sector Activity in the City \\
\hline Townscape Conservation & Social Polarisation and Exclusion \\
\hline
\end{tabular}

Source: Pacione, M., 1999: Applied Geography: Principles and Practice, Routledge, London. 
This paper seeks to demonstrate the fundamental principles and empirical praxis of applied geography. It is organised in two main parts. Part I provides an overview of the principles and practice of applied geography. Consideration is given to the relationship between 'pure' and 'applied' research, and the particular concept of 'useful knowledge' is introduced. This conceptual discussion is complemented, in Part II, by empirical examples of applied research in the field of urban geography. Finally, a prospective perspective is adopted to consider the question of the value of applied geography for contemporary societies.

\section{PART I: PRINCIPLES OF APPLIED GEOGRAPHY}

\section{The Definition of Applied Geography}

An indication of the nature and content of applied geography may be gained by examining a selection of available definitions of the approach. One of the earliest statements on applied geography was offered by A. J. Herbertson in 1899 in a lecture to the Council of the Manchester Geographical Society. In this he defined applied geography as "a special way of looking at geography, a limitation and a specialisation of the study of it from one point of view. For the business man this point of view is an economic one, for the medical man a climatic and demographic one, for the missionary an ethic and ethical one" (Herberston, 1899, 1). While the second part of this definition presents a somewhat restricted view of the context of applied geography even at the end of the nineteenth century, the opening sentence has proved to be a prescient statement which, as we shall see, remains relevant today.

More recent attempts to define applied geography are also instructive as far as they reflect a particular view of the subject. In reviewing several definitions of applied geography Hornbeck $(1989,15)$ identified two common factors in that applied geography "takes place outside the university, and it deals with real world problems". While the latter observation is apposite the exclusion of academic research in applied geography reveals an excessively narrow perspective which, in part, reflects the situation in North America where many applied geographers employ their skills beyond the walls of academia. The extra-mural focus in applied geographical work is also central to Hart's $(1989,15)$ definition which saw applied geography as "the synthesis of existing geographic knowledge and principles to serve the specific needs of a particular client, usually a business or a government agency". The suggestion of uncritical "service to a specific client, whether business or public agency" (Hart, 1989, 17) implicit in this definition ignores the volume of critical analysis undertaken by academic applied geographers.

In a more broadly-based statement Sant $(1982,1)$ viewed applied geography as the use of geographic knowledge as an aid to reaching decisions over use of the world's resources. More specifically, Frazier $(1982,17)$ considered that applied geography "deals with the normative question, the way things should be, a bold but necessary position in dealing with real world problem resolution. In the process, the geographer combines the world of opinion with the world of decision". This latter perspective is closer to the definition of applied geography favoured here. 
Elsewhere, I have proposed a definition of applied geography which reflects the central importance of normative goals and which acknowledges the involvement of both academic and non-academic applied geographers in pursuit of these goals (Pacione, 1999). Accordingly, applied geography may be defined as the application of geographic knowledge and skills to the resolution of social, economic and environmental problems.

The question of how best to attain this goal will be addressed later in the discussion. Here it is appropriate to conclude these introductory comments by examining the academic niche for applied geography, and in the particular question of whether applied geography constitutes a subfield of geography or an approach to the subject. Applied geography is best viewed not as a sub-field of geography but as an approach which can bring together researchers from across the range of subfields in geography either in the prosecution of a particular piece of research or in terms of an enduring commitment to the ethos of the approach (Pacione, 2004a). For applied geography the unifying concept is not a specific model or theory but the fundamental philosophy of relevance or usefulness to society. This 'core', which extends beyond the confines of any single subfield, or indeed discipline, represents a powerful and clearly articulated rationale. Applied geographers would contend that the identification and application of relevant theory, concepts and techniques both from within geography and across disciplinary boundaries is a positive strength of the applied geography approach. Definitions and critiques that seek to establish applied geography as a branch or subfield of geography are misplaced. As Herbertson indicated a century ago, applied geography is best seen not as a subfield but as an approach which can be applied across all branches of the subject.

\section{The Concept of Useful Knowledge}

The concept of useful knowledge will no doubt upset a number of practising geographers. Those who do not see themselves as applied geographers may interpret the concept as indicating a corollary in the shape of geographical research which is less useful or even useless. This would be a misinterpretation. The concept should be seen as an expression of the fundamental ethos of applied geography rather than a design to alienate "non-applied" geographers. The use of the concept represents a deliberate decision to get off the fence and make explicit the view that some kinds of research are more useful than other kinds. This is not the same as saying that some geographical research is better than other work - all knowledge is useful - but some kinds of research and knowledge are more useful than other kinds in terms of their ability to interpret and offer solutions to problems in contemporary physical and human environments.

We shall return to this question later but, in the meantime, it is useful to make explicit the views which underlie the kind of applied geography favoured here. We can do this most clearly by comparing the applied geographical approach with an alternative postmodern perspective. One of the major achievements of postmodern discourse has been the illumination of the importance of difference in society as part of the theoretical shift from an emphasis on economically-rooted structures of dominance to cultural "otherness" focused on the social construction of group identities. However, there is a danger that the reification 
of difference may preclude communal efforts in pursuit of goals such as social justice. As Merrifield and Swyngedouw (1996) observed, a failure to address the unavoidable real-life question of "whose is the more important difference among differences" when strategic choices have to be made represents a serious threat to constructing a practical politics of difference. Furthermore, if all viewpoints and expressions of identity are equally valid, how do we evaluate social policy or, for that matter, right from wrong? How do we avoid the segregation, discrimination and marginalisation which the postmodern appeal for recognition of difference seeks to counteract. The failure to address real issues would seem to suggest that the advent of postmodernism in radical scholarship has done little to advance the cause of social justice. Discussion of relevant issues is abstracted into consideration of how particular discourses of power are constructed and reproduced. Responsibility for bringing theory to bear on real world circumstances is largely abdicated in favour of the intellectually-sound but morally-bankrupt premise that there is no such thing as reality. As Merrified and Swyngedouw (1996, 11) express it "intriguing though this stuff may be for critical scholars, it is also intrinsically dangerous in its prospective definition of political action. Decoupling social critique from its political-economic basis is not helpful for dealing with the shifting realities of life at the threshold of the new millennium". In terms of real world problems postmodern thought would condemn us to inaction while we reflect on the nature of the issue. (As we shall see below, a similar critique may be levelled at the Marxist critique of applied geography which was prevalent during the 1970 s and 1980s).

The views expressed in the above discussion do not represent an attempt to be prescriptive of all geographical research but are intended to indicate clearly the principles and areas of concern for applied geography. It is a matter of individual conscience whether geographers study topics such as the iconography of landscapes or the optimum location for health centres, but the principle underlying the kind of useful geography espoused by most applied geographers is a commitment to improving existing social, economic and environmental conditions. There can be no compromise - no academic fudge - some geographical research is more useful than other work; this is the focus of applied geography.

Of course there will continue to be divergent views on the content and value of geographical research. This healthy debate raises a number of important questions for the discipline and for applied geography in particular. The concept of "useful research" poses the basic questions of useful for whom?, who decides what is useful?, and based on what criteria? All of these issues formed a central part of the "relevance debate" of the early 1970s (Chisholm, 1971; Prince, 1971; Smith, 1971; Dickenson and Clarke, 1972; Berry, 1972). The related questions of values in research, and the nature of the relationship between pure and applied research are also issues of central importance for applied geography. These are addressed in the following sections.

\section{The Relationship Between Pure and Applied Research}

The development of applied geography has been accompanied by debate over the relative merits of pure and applied research. Critics such as Cooper (1966) and more 
recently Kenzer (1989) warned against the application of geographical methods as a threat to the intellectual development of the discipline. Conversely, Applebaum (1966) took the view that "geography as a discipline has something useful to contribute to man's struggle for a better and more abundant life. Geographers should "stand up and be counted among the advocates and doers in this struggle" (Applebaum, 1966, 198). In similar vein, Abler (1993) considered that "too many geographers still preoccupy themselves with what geography is; too few concern themselves with what they can do for the societies that pay their keep" (Abler, 1993, 225). There is no reason why an individual researcher cannot maintain a presence in both pure and applied research. The eminent American geographer C. Sauer was both a "scholar" who conducted research on agricultural origins and dispersals and an "applied geographer" who developed a land classification system for the State of Michigan. The terms pure and applied are best seen as the ends of a continuum rather than unrelated polar opposites.

According to Palm and Brazel $(1992,342)$ "applied research in any discipline is best understood in contrast with basic, or pure, research. In geography, basic research aims to develop new theory and methods that help explain the processes through which the spatial organisation of physical or human environments evolves. In contrast, applied research uses existing geographic theory or techniques to understand and solve specific empirical problems".

While this distinction is useful at a general level it overplays the notion of a dichotomy between pure and applied geography, which are more correctly seen as two sides of the same coin. There is, in fact, a dialectic relationship between the two. As Frazier $(1982,17)$ points out "applied geography uses the principles and methods of pure geography but is different in that it analyses and evaluates real-world action and planning and seeks to implement and manipulate environmental and spatial realities. In the process, it contributes to, as well as utilizes, general geography through the revelation of new relationships". Clearly, theory and praxis are essential companions. Applied research provides the opportunity to use theories and methods in the ultimate proving ground of the real world, as well as enabling researchers to contribute to the resolution of real world problems. Theory provides the framework for asking questions about the substantive relationships embodied in a problem. In urban geography, for example, social theory provides a normative standard against which current and future social conditions may be judged in terms of defined moral goals (which may address issues such as whether a minimum wage and basic standard of living should be a legal entitlement in advanced capitalist societies).

There is little merit in pursuing a false dichotomy between pure and applied research. A more useful distinction is that which recognises the different levels of involvement of researchers at each stage of the research and specifically the greater engagement of applied geographers in the 'downstream' or post-analysis stages (Fig. 1). The applied researcher has a greater interest than the pure researcher in taking the investigation beyond analysis into the realms of application of results and monitoring the effects of proposed strategies. Researcher participation in the implementation stage may range from recommendations in scholarly publications or contracted reports (a route favoured by most academic applied geographers, though not exclusively) to active involvement in implementation (more 
usually by applied geographers employed outside academia). Between these positions lie a variety of degrees of engagement, including acting as expert witnesses at public enquiries, dissemination of research findings via the media, field involvement in, for example, landscape conservation projects, and monitoring the effects of policies and strategies enacted by governmental and private sector agencies.

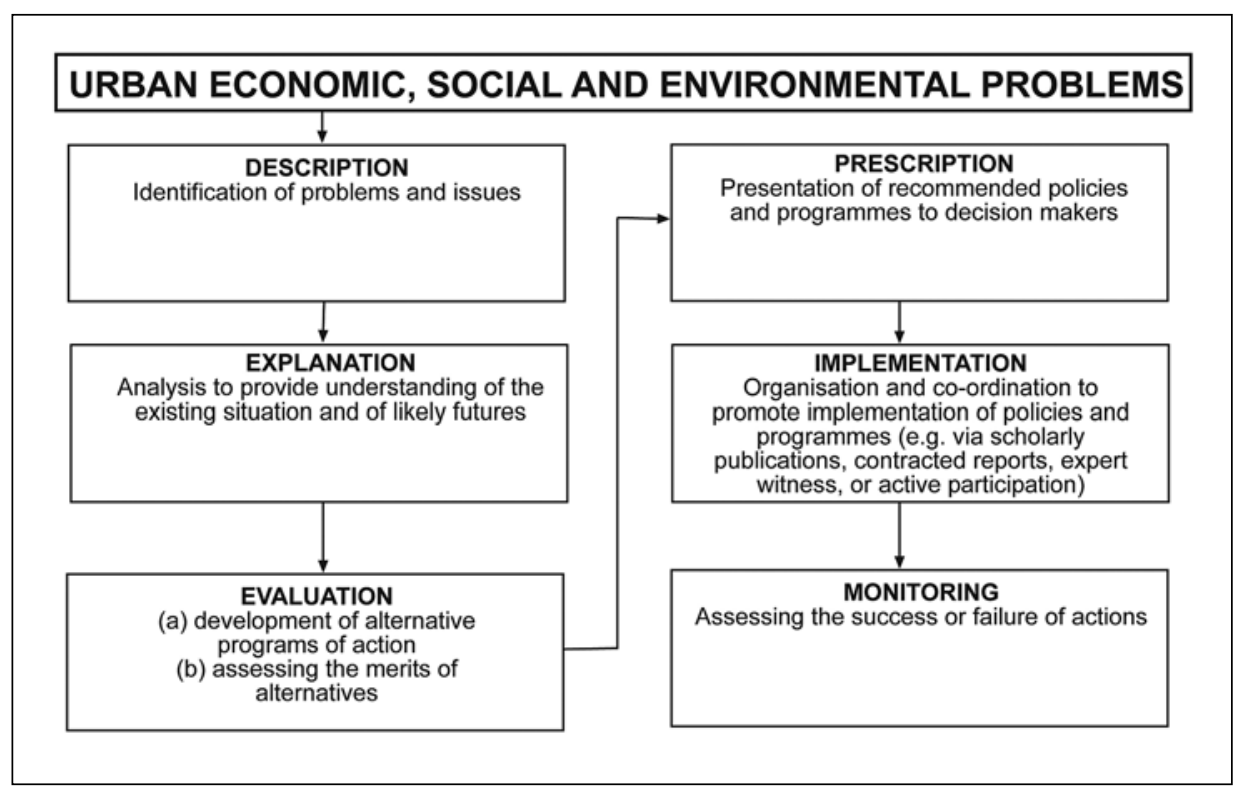

Fig. 1 A protocol for applied geography

Sl. 1. Protokol za primijenjenu geografiju

The balance between pure and applied research within a discipline varies over time in relation to the prevailing socio-political environment. When external pressures are at their greatest disciplines will tend to emphasise their problem-solving capacity while during periods of national economic expansion "more academic" activity may be pursued in comfort. Taylor (1985) equated these cycles with the long waves of the world economy, and identified three periods in which applied geography was in the ascendancy (in the late nineteenth century, inter-war era, and mid-1980s) separated by two periods of pure geography (in the early twentieth century, and during the post-1945 economic boom) (Tab. 2). More recently, the global recession of 2009 has led to demands from the UK government and research funding bodies for academic research to demonstrate its (applied) beneficial impact for the nation's economy and society. 
Tab. 2 Cycles of pure and applied geography

Tab. 2. Ciklusi temeljne i primijenjene geografije

\begin{tabular}{|l|l|}
\hline $\begin{array}{l}\text { First Applied Period } \\
\text { (late nineteenth century) }\end{array}$ & $\begin{array}{l}\text { Geography created as an applied discipline to serve the political, } \\
\text { military and commercial interests of the Prussian state. }\end{array}$ \\
\hline $\begin{array}{l}\text { First Pure Period } \\
\text { (early twentieth century) }\end{array}$ & $\begin{array}{l}\text { Based around the holistic philosophy encompassing both physical } \\
\text { and human phenomena and focused on the core concept of the } \\
\text { region and regional synthesis. }\end{array}$ \\
\hline $\begin{array}{l}\text { Second Applied Period } \\
\text { (inter-war) }\end{array}$ & $\begin{array}{l}\text { A period of war, followed by Depression, and war again deman- } \\
\text { ded geography demonstrate its usefulness in fields such as land } \\
\text { use planning. }\end{array}$ \\
\hline $\begin{array}{l}\text { Second Pure Period } \\
\text { (post 1945 boom) }\end{array}$ & $\begin{array}{l}\text { Rejection of ideographic, regionalism replaced by spatial science } \\
\text { and the quantitative revolution; demise of holistic approach and } \\
\text { emergency of subfields within the discipline. }\end{array}$ \\
\hline $\begin{array}{l}\text { Third Applied Period } \\
\text { (mid 1980s) }\end{array}$ & $\begin{array}{l}\text { Extension of the concept of useful research into new areas of } \\
\text { concern relating to social, economic and environmental problems; } \\
\text { applied geographers working both in academic and in public and } \\
\text { private sectors. Applied geography as an approach rather than } \\
\text { a subfield crosscuts the artificial boundary between physical } \\
\text { and human geography and emphasises the dialectic relationship } \\
\text { between pure and applied research. Acknowledgement of the } \\
\text { role of human agency and values in research and environmental } \\
\text { change, and the need for a pluralist view of science. }\end{array}$ \\
\hline Third Pure Period (?) & $\begin{array}{l}\text { Characteristics unknown but speculatively - a return to a more holi- } \\
\text { sticphilosophy reflecting the growing importance of environmental } \\
\text { issues and the combinatory perspective of applied geography. }\end{array}$ \\
\hline $\begin{array}{l}\text { Fourth (emerging?) } \\
\text { Applied Period } \\
\text { (post-2009 Global recession) }\end{array}$ & $\begin{array}{l}\text { Increasing demands from governments and research funding } \\
\text { councils for researchers to demonstrate the applied beneficial } \\
\text { impacts of their research for contemporary economy and society. }\end{array}$ \\
\hline
\end{tabular}

\section{The Value of Applied Geography}

A fundamental question for those working within the framework of applied geography concerns the value of a problem-oriented approach. We have examined this issue already in our discussions of useful knowledge and the relationship between pure and applied research but we return to it here to address the specific critique of applied geography which has emanated from Marxist theorists. The argument in favour of a Marxist approach was presented by Folke (1972) who considered that geography and the other social sciences are "highly sophisticated, technique-oriented, but largely descriptive disciplines with little relevance for the solution of acute and seemingly chronic social problems .... theory has reflected the values and interests of the ruling class" (Folke, 1972, 13). While the power of the Marxist critique has been much reduced by its own success in exposing the value-bases of research it still offers a useful perspective on the value of applied research.

The essence of the Marxist critique of applied social research is that it produces ameliorative policies which merely serve to patch up the present system, aid the legitimation of the state, and bolster the forces of capitalism with their inherent tendencies to create inequality. For these radical geographers participation in policy evaluation and 
formulation is ineffective since it hinders the achievement of the greater goal of revolutionary social change.

In terms of praxis the outcome of this perspective is to do nothing short of a radical re-construction of the dominant political economy (a position which, as we have seen, may also be reached from a different direction by postmodernist theorists). Although the analytical value of the Marxist critique of capitalism is widely acknowledged its political agenda, and in particular opposition to any action not directed at revolutionary social change, finds little favour among applied geographers. To ignore the opportunity to improve the quality of life of some people in the short term in the hope of achieving possibly greater benefit in the longer term is not commensurate with the ethical position implicit in the problem-oriented approach of applied geography.

Neither does the argument that knowledge is power and a public commodity that can be used for good or evil undermine the strength of applied geography. Any knowledge could be employed in an oppressive and discriminating manner to accentuate inequalities of wealth and power but this is no argument for eschewing research. On the contrary, it signals a need for greater engagement by applied geographers in the policy-making and implementation process provided, of course, that those involved are aware of and avoid the danger of co-optation by, for example, funding agencies.

Furthermore, access to the expertise and knowledge produced by applied geographical research is not the sole prerogative of the advantaged in society, but can be equally available to pressure groups or local communities seeking a more equiTab. share of society's resources. As Frazier $(1982,16)$ commented, applied research "involves the formulation of goals and strategies and the testing of existing institutional policies within the context of ethical standards as criteria. This should not imply a simple system maintenance approach to problem solving. Indeed, it is often necessary to take an unpopular anti-establishment position, which can result in a major confrontation". For practical examples of this we need only refer to the pragmatic radicalism practised by the Cleveland City Planning Commission (Kraushaar, 1979); the recommendations of the British Community Development Projects which advocated fundamental changes in the distribution of wealth and power and which led to conflict with both central and local government; as well as more recent policy-oriented analyses of poverty and deprivation in which the identification of socio-spatial patterns is used to advance a critique of government policy (Pacione, 1990a; Pacione, 2004b).

\section{Values in Applied Geography}

At each stage of the research process the applied geographer is faced with a number of methodological and ethical questions. Decisions are required on defining the nature of the problem, its magnitude, who is affected and in what ways, as well as on the best means of addressing the problem. All of these require value judgements on, for example, the acceptability of existing conditions (what is an accepTab. level of air pollution? or of infant malnutrition?). Values are also central to the evaluation and selection of possible remedial strategies, including comparative analysis of the benefits and disbenefits of different approaches for different people and places. In some cases the applied geographer 
may seek to minimise such value judgements by enhancing the objectivity of the research methodology (for example, by employing a classification of agricultural land capability to inform a set-aside policy). In most instances, however, it is impossible to remove the need for value judgement. As Briggs $(1981,4)$ concluded, "whether objectivity is ever achieved is a moot point. In most cases the subjectivity is merely transferred from the client (for example the politician or the planner) to the research designer". The impossibility of objective value-free research is now axiomatic.

One issue of particular concern refers to the values that condition the selection, conduct and implementation of research, a dilemma highlighted by the aphorism "he who pays the piper calls the tune". J. T. Coppock $(1974,9)$, an advocate of public policy research by applied geographers, expressed this in terms of "doubts over whether government departments will commission necessary research into the effectiveness and consequences of their own policies and there is a real danger that constraints will be imposed over publication, especially if this contains criticisms of the sponsors or explores politically sensitive areas". Applied geographers must beware of any restrictions imposed by research sponsors and aware of the ways in which their research results may be used. Decisions on whether to undertake a project must weigh the benefits against any constraints imposed by a client or sponsor. In general, applied geographers should seek to ensure that their work contributes to human welfare. In practice this goal may be approached by careful selection of clients and research projects, by ensuring freedom to disseminate results and, where possible, through engagement in the implementation and monitoring of relevant policy or strategies. This leads to consideration of a possible protocol for the practice of applied geography.

\section{A Protocol for Applied Geography}

There is no single method of doing applied geographical research. Nevertheless it is useful to examine one possible protocol which, with appropriate methodological modifications to suit the task in hand, can provide a framework for many investigations in applied geography.

The procedure may be summarised as description, explanation, evaluation and prescription (DEEP) followed by implementation and monitoring (Fig.1). The "DEEP" procedure represents a useful analytical algorithm. However, the apparent clarity and organisation of the scheme does not imply that simple answers are expected to contemporary social, economic or environmental problems. Normally, in order to understand the nature and causes of real world problems it is necessary to untangle a Gordian knot of causal linkages which underlie the observed difficulty. In some cases, such as the link between ground slippage and building collapse, cause and effect are relatively straightforward. But in most instances the cause of a problem may be more apparent than real. Thus while the immediate cause of the problems faced by a poor family on a deprived council estate in Liverpool may be a lack of local employment opportunities following the closure of a factory, the root cause of the social and financial difficulties confronting the family may lie in the decisions of investment managers based in London, New York or Tokyo.

As Fig. 1 indicates, as well as describing the nature and explaining the causes of problems the applied geographer also has a role to play in evaluating possible responses 
and in prescribing appropriate policies and programmes which may be implemented by planners and managers in both the public and private sectors, or by the residents of affected communities. In performing these tasks the applied geographer will be confronted with a variety of potential responses for any problem. The selection of appropriate strategy is rarely straightforward. The decision must be based on not only technical criteria but also on a wide range of conditioning factors including the views and preferences of those affected by the problem and proposed solution, available finance, and externality considerations or how the strategy to resolve a particular problem (such as construction of flood control levees) may affect other problems (such as increased flooding of downstream communities).

As indicated earlier, applied geographers, in contrast to "pure" geographers, may also be involved in the implementation stage of the research, normally in a supervisory or consultancy capacity to ensure effective application of a strategy. The nature of any engagement is potentially wide ranging, for example, from overseeing the setting-up of a computer-based route planning system for a private transport company or public ambulance service to making one's expertise available to community groups seeking to establish a housing co-operative or local economic development initiative. Finally, as Fig. 1 reveals, applied geographers may be involved in monitoring the impacts of policies and programmes implemented to tackle a problem, and in relating these critically to predetermined normative goals.

\section{PART II: PRACTISING APPLIED GEOGRAPHY}

In the second part of the paper we complement the foregoing discussion of the philosophical and conceptual bases of applied geography by presenting two examples of applied research drawn from the field of urban geography. In these empirical case studies we focus particular attention on the key issue of quality of life and human well being.

\section{The Urban Environment and Human Wellbeing}

Growing concern for the future of cities and for the well-being of city dwellers, stimulated by trends in world urbanisation, the increasing number and size of cities, and the deterioration of many urban environments, has focused attention on the problems of living in the city. Central to this concern is the relationship between people and their everyday urban environments. Understanding the nature of the person-environment relationship is a quintessential geographical problem. In the context of the built environment this can be interpreted as a concern with the degree of congruence or dissonance between city dwellers and their urban surroundings, or the degree to which a city satisfies the physical and psychological needs and wants of its citizens. Urban geographers involved in research into 'quality of life' (Pacione, 2005) and 'urban liveability' (Pacione, 1990b) are making a significant contribution to our understanding of the relationship between people and their urban environments.

Fig. 2 illustrates the place of urban quality of life research within human geography. While research into differential quality of life may be undertaken at both inter-urban and intra-urban scales the majority of geographical research into quality of life has focused 


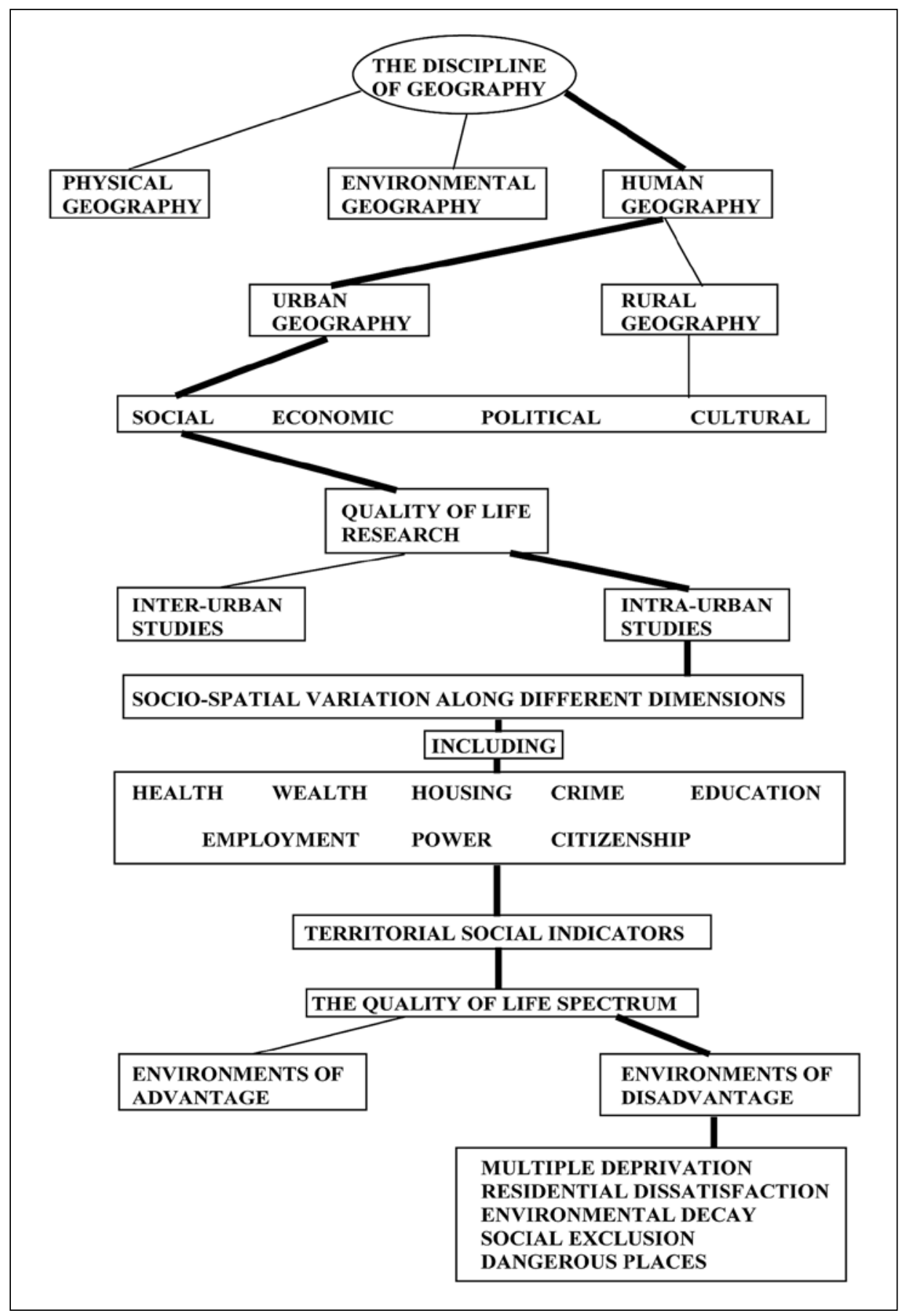

Fig. 2 An applied urban geographical perspective on quality of life

Sl. 2. Pristup proučavanju kvalitete života iz urbano-geografske perspektive 
on the intra-urban scale, and on conditions at the disadvantaged end of the quality of life spectrum. The contemporary social significance of this research is underlined by the fact that the problems of poverty and deprivation experienced by people and places marginal to the capitalist development process have intensified over recent decades. In the UK, during the 1980s, poverty increased faster than in any other member state of the EU so that by the end of the decade one in four of all poor families in the Community lived in Britain (Lansley and Mack, 1991). Furthermore, over subsequent decades the levels of inequality in British society have proved resistant to change (Hills, 2010).

As Fig. 2 shows, geographical research on differential quality of life at the intra-urban scale seeks to identify socio-spatial variations in quality of life, or human well-being, along a number of dimensions including, for example, health, wealth, housing and crime. Mapping of differential quality of life aids identification of urban 'environments of advantage' (elite areas) and 'environments of disadvantage' - characterised by a range of social, economic and environmental problems. The applied or problem-oriented perspective that underlies this work - and that is central to the goal of creating a liveable city, (as well as liveable neighbourhoods and communities), - means that particular attention is focused on 'environments of disadvantage' within contemporary cities.

Study of conditions at the disadvantaged end of the quality of life spectrum forms a key area of research in contemporary applied urban geography. As Fig. 3 shows, poverty

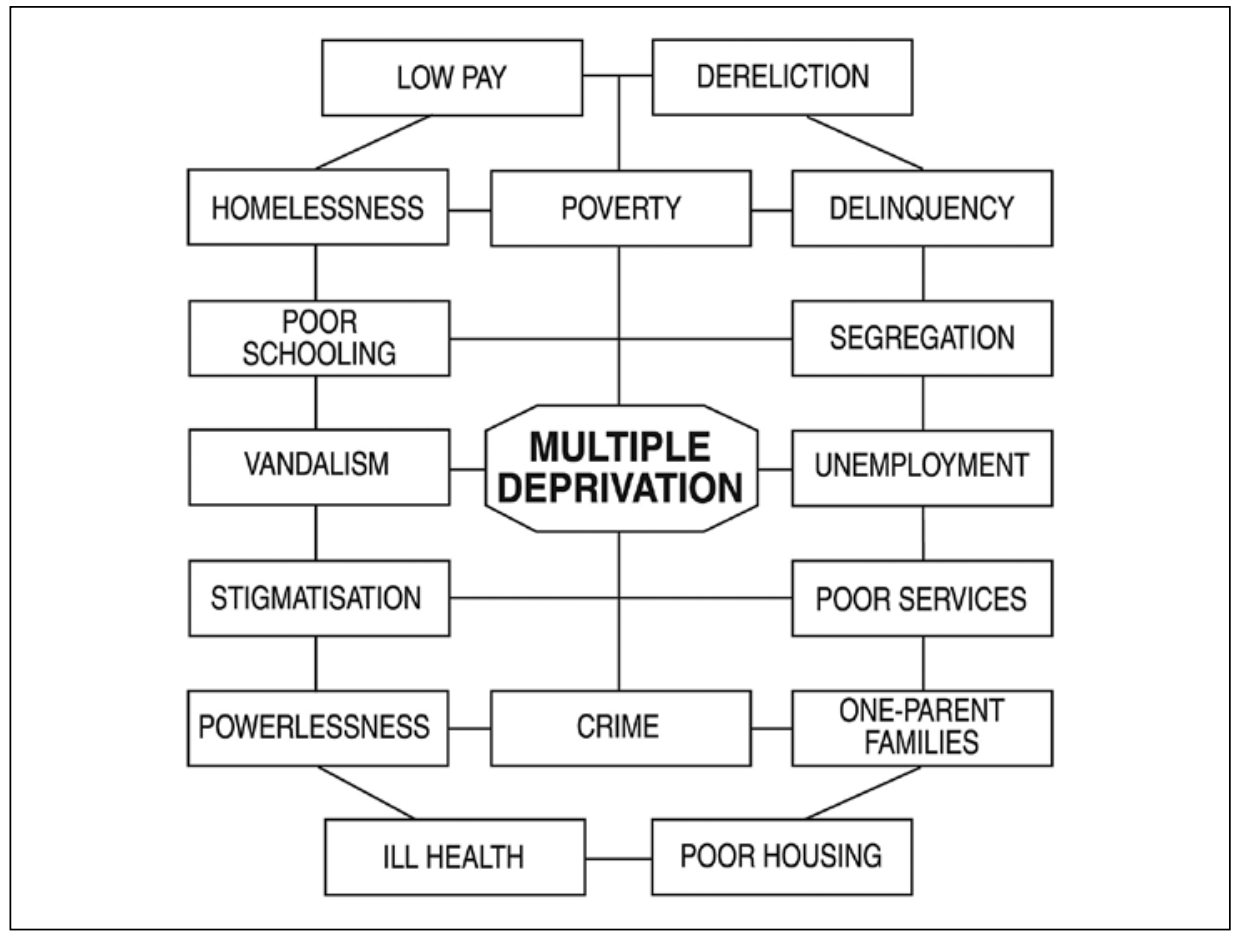

Fig. 3 The anatomy of multiple deprivation

Sl. 3. Anatomija višestruke deprivacije 
is a central element in the multi-dimensional problem of deprivation in which individual difficulties reinforce one another to produce a situation of compound disadvantage for those affected. Significantly, the complex of poverty-related problems such as crime, delinquency, poor housing, unemployment and increased mortality and morbidity has been shown to exhibit spatial concentration in cities. This patterning serves to accentuate the effects of poverty and deprivation for the residents of particular localities. In the United Kingdom, for example, the decline in status of some inner city areas and peripheral social housing estates has been revealed by socio-spatial analyses which showed high concentrations of the unemployed, the low skilled, the aged and ethnic minorities accompanied by high levels of overcrowding, amenity deficient housing, environmental decay, political powerlessness, social polarisation and stigmatisation, and social pathologies such as low levels of educational achievement and high rates of crime and of single parent households (Pacione, 1982; 1986a; 1986b; 1987; 1989a; 1989b; 1993; 1995a, 1995b; 1995c; 1997; 2003; 2004c; 2009).

Understanding the geography of multiple deprivation is a key area of applied research in urban social geography. We can illustrate this with reference to the city of Glasgow, UK.

\section{Case Study 1 - The Geography of Multiple Deprivation in Glasgow}

In this research a combination of statistical and cartographic analysis was employed to identify the nature, intensity and incidence of multiple deprivation in the city. A set of 64 objective territorial indicators relating to demographic, social, economic and residential conditions was extracted from the census for each of the 5374 output areas in Glasgow. The data set was subjected first to univariate analysis to examine the distributions of individual social indicators across the city. While examination of each of the 64 indicators is of both academic and practical utility in its own right, the univariate analyses suggested some degree of statistical and spatial overlap among the revealed patterns. An R-type principal components analysis was used to explore the weave of linkages among the individual

Tab. 3 Component structures and loadings - multiple deprivation

Tab. 3. Struktura i zasićenost komponenata - višestruka deprivacija

\begin{tabular}{|c|c|}
\hline Component 1: multiple deprivation & Loading \\
\hline \% male unemployment & 0.7511 \\
\hline \% occupying council (social) housing & 0.4896 \\
\hline \% households with $>1.5$ persons per room & 0.5183 \\
\hline \% household spaces vacant & 0.4906 \\
\hline \% households with single person < pension age & 0.5261 \\
\hline \% households of single parents & 0.6617 \\
\hline \% travel to work by bus & 0.3189 \\
\hline \% household heads in lowest socio-econ groups & 0.3000 \\
\hline \% young children living in high flats & 0.6019 \\
\hline \% households above the occupancy norm & 0.6935 \\
\hline
\end{tabular}




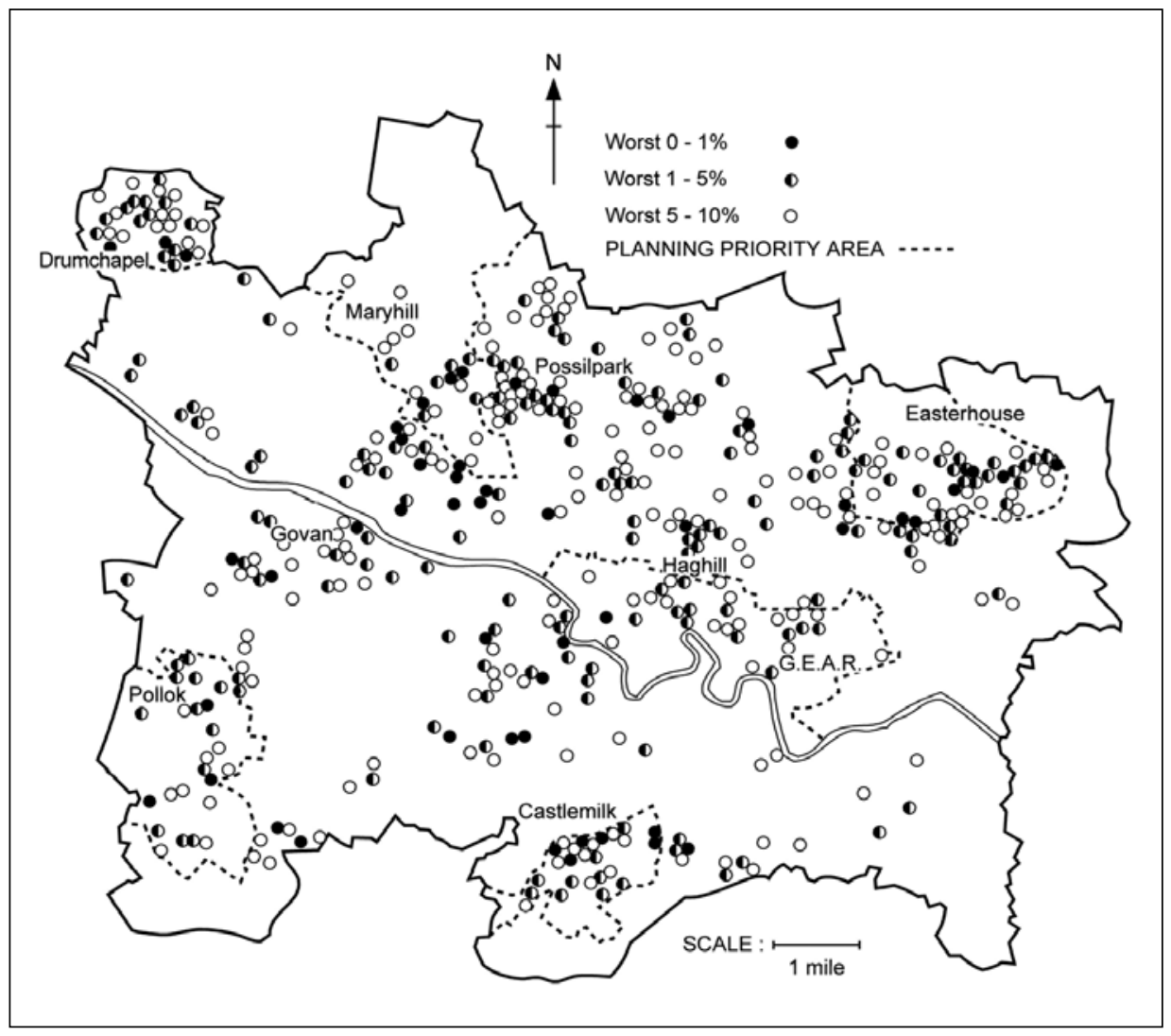

Fig. 4 The geography of multiple deprivation in Glasgow

Sl. 4. Geografija višestruke deprivacije u Glasgowu

distributions, and to provide a conceptually and statistically rigorous composite measure of multiple deprivation. In this study the principal component was readily identified as an indicator of multiple deprivation, with high correlations among measures relating to male unemployment, council/social housing, single-parent households, and overcrowded housing (Tab. 3).

Calculation of component scores provided a measure of deprivation for each of the 5374 census output areas in the city. Mapping these scores revealed the spatial expression of multiple deprivation in Glasgow (Fig. 4).

This research identified the nature, intensity and incidence of multiple deprivation within the city. In addition, such research by identifying the major loci of deprivation ('environments of disadvantage') provides a basis for detailed analyses of particular problems and problem areas. The analytical results also provide a base for critical assessment of policies aimed at alleviating conditions of disadvantage. In addition, longitudinal studies can map the changing geography of multiple deprivation in the city over time. 


\section{Case Study 2 - Landscapes of Fear in the City}

A second exemplar of the applied geographical approach to mapping differential quality of life illustrates the use of subjective social indicators to gauge gender-differentiated fear of crime at the local level within the city. Fear of crime is a growing social problem, a major policy issue and an important element in the social geography of contemporary cities. For the most vulnerable sub-groups of the population living in high-risk environments the impact of fear of crime on daily living patterns and on general quality of life can be profound. A major obstacle to addressing this social stressor is lack of detailed information on fear of crime at the neighbourhood scale. This research was designed to gauge the nature and extent of fear of crime among male and female residents of a deprived social housing estate on the edge of Glasgow, and to identify geographies of fear within the area. For both males and females crime was regarded as the second most serious problem in the area (Tab. 4). Related social problems were identified in references to the general unfriendliness of the locality and bad relations between residents and the police. Fear of assault and burglary were the most prevalent crime risk reported (Tab. 5).

Tab. 4 Perceived life problems in the study area

Tab. 4. Percipirani životni problemi u proučavanom području

\begin{tabular}{|c|c|c|c|c|}
\hline Problem & Males & Females & Total & Overall Rank \\
\hline Unenployment & 83.7 & 82.9 & 83.3 & 1 \\
\hline Poor schooling & 26.1 & 22.0 & 24.1 & 8 \\
\hline Bad housing & 73.0 & 70.6 & 71.8 & 3 \\
\hline Crime & 80.3 & 79.9 & 80.1 & 2 \\
\hline Lack of leisure & 53.9 & 49.9 & 51.9 & 4 \\
\hline Lack of spaces & 34.6 & 28.3 & 36.5 & 5 \\
\hline General unfriendliness & 32.6 & 33.0 & 32.8 & 6 \\
\hline Bad relations with police & 30.4 & 29.0 & 29.7 & 7 \\
\hline
\end{tabular}

Tab. 5 Perceived risk from different forms of crime

Tab. 5. Percipirani rizici od različitih oblika kriminala

\begin{tabular}{|c|c|c|}
\hline Nature of risk & Males & Females \\
\hline Assault & 56.1 & 27.4 \\
\hline Sexual assault & 0.0 & 31.5 \\
\hline Burglary & 37.8 & 29.0 \\
\hline Car theft & 4.5 & 5.2 \\
\hline Street theft & 0.0 & 6.9 \\
\hline Arson & 1.0 & 0.0 \\
\hline
\end{tabular}

The investigation revealed clear gender-based differences in the fear of crime. For most young males the high risk of assault was an accepted part of their lifestyle and living environment. Respondents accepted that they are "fair game" and an automatic target for 
Tab. 6 Perceived danger areas

Tab. 6. Percipirana opasna područja

\begin{tabular}{|c|c|c|}
\hline Locations & Males & Females \\
\hline Parks & 7.6 & 19.7 \\
\hline Gang neighbourhoods & 34.0 & 14.9 \\
\hline Bridges and overpases & 0.0 & 11.9 \\
\hline Playing fields & 6.8 & 9.5 \\
\hline Schools & 8.2 & 7.1 \\
\hline Peripheral roads/spaces & 0.0 & 20.8 \\
\hline Town centre & 43.4 & 16.1 \\
\hline
\end{tabular}

local gangs. The relative physical weakness of young females fostered a fear of assault and in particular sexual assault. These perceptions of risk conditioned the daily activity patterns of people living on the estate. Young males took care to avoid known gang territories, and the town centre in the evenings. Females were particularly wary of parks and other open spaces including periphery roads, bridges and over/underpasses (Tab. 6).

The information on respondents' cognitive maps of fear was used to identify specific 'danger areas' within the study area (Fig. 5). Clearly, analysis of the particular characteristics of these dangerous spaces may contribute to the design of policies aimed at reducing fear of crime in the locality, and to the enhancement of life quality for residents.

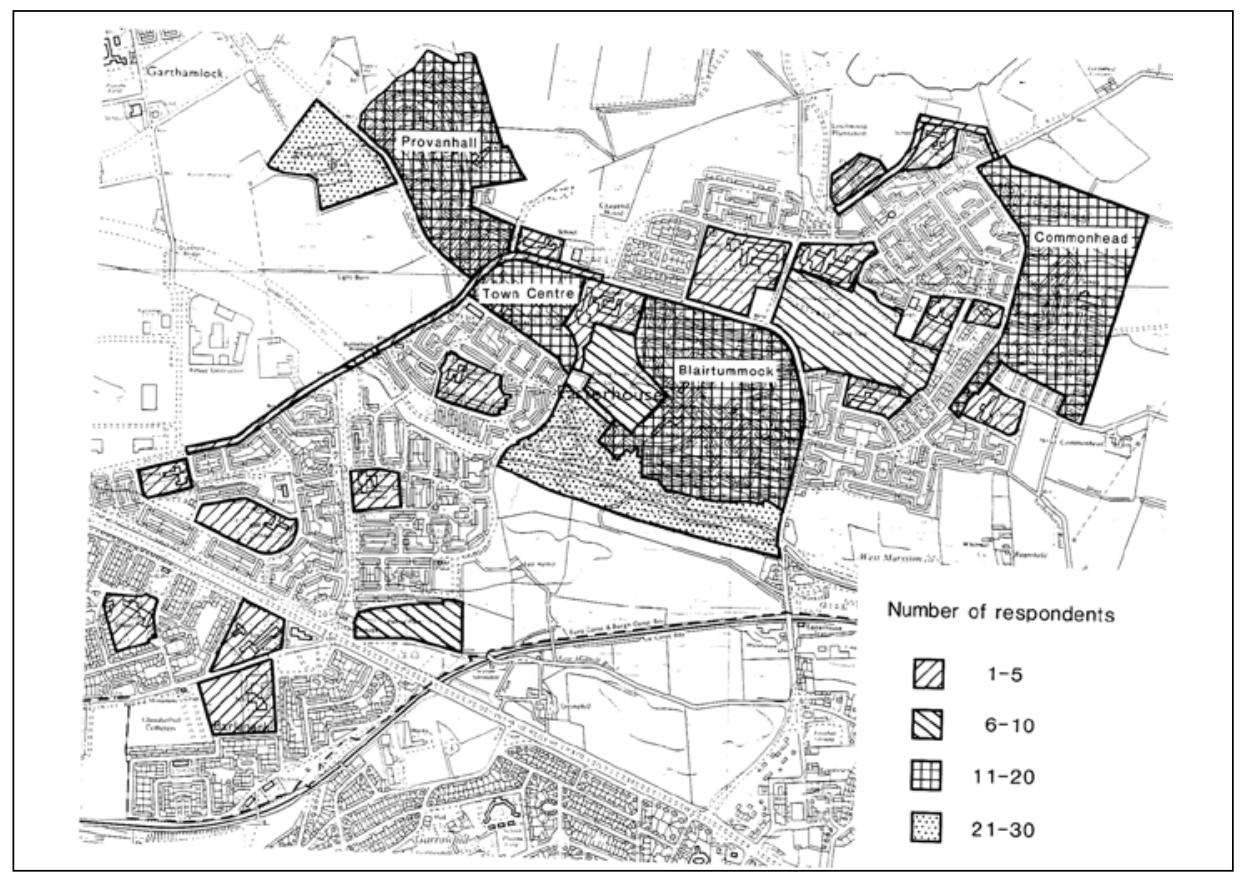

Fig. 5 Females' geography of fear in the study area

Sl. 5. Ženska geografija straha u proučavanom području 
Together these example studies underline the fact that in order to obtain a proper understanding of the quality of urban lifespace it is necessary to employ both objective and subjective evaluations. In short, we must consider both the city on the ground and the city in the mind.

\section{Applied Geography: Prospective}

The practical value of the applied geographical approach has been demonstrated in the foregoing discussion of the principles and praxis of applied geography. Applied geographers are actively engaged in investigating the causes and ameliorating the effects of "natural" phenomena including acid precipitation, landslides and flooding. Key issues of environmental change and management also represent a focus for applied geographical research with significant contributions being made in relation to a host of problems ranging from the quality and supply of water, deforestation and desertification to a series of land use issues including agricultural de-intensification, derelict and vacant land and wetland and townscape conservation. Applied geographers with a particular interest in the built environment have, in recent decades, directed considerable research attention to the gamut of social, economic and environmental problems which confront the populations of urban and rural areas in both the Developed and Developing realms. Problems of housing, poverty, crime, transport, ill-health, socio-spatial segregation and discrimination have been the subject of investigation, while other topics under examination include problems ranging from boundary disputes and political representation to city marketing. The application of techniques in applied geographical analysis is of particular relevance in relation to spatial analyses where the suite of problems addressed by applied geographers ranges from computer mapping of disease incidence to simulation and modelling of the processes of change in human and physical environments.

The list of research undertaken by applied geographers is impressive but there are no grounds for complacency. While applied geographers have made a major contribution to the resolution of real world problems, particularly in the context of the physical environment, in terms of social policy formulation in the post-war era the influence of applied geography has been mixed and arguably less than hoped for by those socially-concerned geographers who engaged in the relevance debate over a quarter of century ago. Massey (2001) suggests that as geographers 'we may be underplaying our hand'; while Martin (2001) questions why geographers play 'second fiddle' to other academics in areas where we should be making the main impact.

Several reasons may be proposed to account for this impact deficit. The first refers to the eclectic and poorly-focused nature of Geography. Clifford (2002) refers to a 'bewildering and burgeoning array of 'geographies'. The very breadth of the discipline, which for many represents a pedagogic advantage, may blur its image as a point of reference for decision-makers seeking an informed input. (I refer to this as 'the cocktail party syndrome' - "Oh, you're a Geographer: what do you do?")

The changing content and shifting emphases of human geography during the last quarter of the twentieth century represents a further factor underlying the limited social impact of applied geography. Over the period the replacement of the earlier land use focus 
in applied human geography by questions relating to the geography of poverty, crime, health-care, ethnic segregation, education and the allocation of public goods brought applied geographers into direct confrontation with those responsible for the production and reproduction of these social problems. Unsurprisingly, since policy-makers are resistant to research which might undermine the legitimacy of the dominant ideology, social policy remained largely impervious to geographical critique, particularly that which emanated from the Marxist analysis of capitalism.

Another issue is the fact that "geographical" work is often undertaken by "non-geographers" in other disciplines. This undermines the image of geography as a subject with something particular to offer in public policy debate. Geographers wishing to influence public policy must compete with other more clearly identified "experts" working on similar themes. Blij (2005) warns of the scholarly and academic costs in not demonstrating to the academic community, government and public at large that geographers have the necessary skills to contribute effectively to the resolution of some of the major problems facing society.

A further reason for the relatively limited influence of geography on public policy may be the apparent reluctance of (human) geographers to "get their hands dirty" with applied work. This criticism adheres less to research in physical geography where a basis in empirical science and positivist methodology has ensured that applied research has attracted support and acclaim more readily both from within the discipline and from external agencies. Significantly, the growth of environmentalism and of debates over sustainable development has gone some way to bridge the philosophical and methodological gap between physical and human geography, and may represent a route for applied geographers to increase their policy influence.

Part of the explanation for geography's marginality in policy debate and formulation is the tendency for geographers to target our communications primarily at one another (Murphy, 2006). Geographers need to speak more clearly and communicate with 'ordinary people' in straightforward language without jargon and arcane vocabularies (Blomley, 1994).

In similar vein, it must be recognised that successful academic research alone is no longer sufficient. To ensure appropriate use of findings by public and private agencies and decision-makers, researchers must seek to develop direct channels of communication to link scientific findings to policy objectives. As Lees (2003) observes, "what is the point of a substantial, critical and rigorous academic literature... if it is not actively disseminated to those in a position to influence and make the policies we seek to inform'.

The radical idealism of the socially-concerned geography of the 1970s was resisted easily by the forces of political reality. Since that time social policy has remained largely impervious to geographical critique. This is not due to incompetent analysis or prognosis but reflects the failure of human geographers to place their work within a moral framework that can command the support of the population at large. As we have seen this condition was not satisfied by the Marxist critique of capitalism and its radical prognosis for social redistribution. It should be apparent by now that any attempt to engage more effectively with policy analysis and formulation must temper idealism with realism.

In the context of advanced capitalism this requires acceptance of several premises. The first is clear cut. Market capitalism is here to stay for the foreseeable future. While 
the excessive inequalities of a market society is repudiated by those seeking a more just distribution of society's resources, all must acknowledge that wealth creation and wealth distribution are two sides of the same coin and that the capitalist mode of production is the most efficient engine of wealth production available. Equally, however, markets (for labour, finance, goods and services) are not created by natural or divine forces but are the product of the values, institutions, regulations and political decisions that govern them. What is required in creating an alternative moral philosophy, and greater geographical influence on policy makers, is not rejection of the market but a shift in balance between social and economic considerations. What is needed is a social view of economics to replace the present economic view of society. This requires progress towards objectives that include socially-concerned as opposed to maximum economic growth, inclusive democracy, gender and racial equality, and inter-generational equity. The volume of quality of life research undertaken in urban geography since the 1980s provides a solid foundation for further efforts to inject a geographical perspective into political and policy-making processes. However, as indicated in Tab. 2, the possibility of achieving this ideal is conditioned by the reality of global, national and local economic and social context.

The relative failure of applied geography to exert a major influence on social policy, however, does not signal a failure of applied geography to promote any significant improvement in human well-being which, as we have seen, may be achieved by means other than via public policy. Any assessment of the contribution of applied geography to the resolution of real world problems must balance the limited success in the specific area of social policy against the major achievements of applied geographers in a large number of other problem areas indicated in Tab. 1.

Applied geography is an approach whose rationale is based on the particular philosophy of relevance or social usefulness and which focuses on the application of geographical knowledge and skills to advance the resolution of real world social, economic and environmental problems. Applied geographers are active across the human-physical geography divide and in most sub-areas of the discipline. The range of applied research being undertaken illustrates not only the contribution that applied geography is currently making towards the resolution of social, economic and environmental problems at a variety of geographic scales, but also the potential of the approach to address the continuing difficulties which confront humankind. Applied geography is a socially-relevant approach to the study of the relationship between people and their environments. The principles, practice and potential of applied geography to engage a wide range of real world problems commends the approach to all those concerned about the quality of present and future living conditions and environments on the planet Earth.

\section{REFERENCES}

Abler, R., 1993: Desiderata for geography: an institutional view from the U.S., in: The Challenge for Geography (ed. Johnston, R.J.), Blackwell, Oxford, 215-238.

Applebaum, W., 1966: Communications from readers, Professional Geographer 18 (3), 198-199. 
Berry, B., 1972: More on relevance and policy analysis, Area 4 (2), 77-80.

Blij, H., 2005: Raising geography's public profile in public debate (167-173), in: The Role of Geography in Public Debate (ed. Murphy, J.), Progress in Human Geography 29 (2), 165-193.

Blomley, N., 1994: Activism and the academy, Environment and Planning D 12 (4), 383-385.

Briggs, D., 1981: Editorial: the principles and practice of applied geography, Applied Geography 1 (1), 1-8.

Chisholm, M., 1971: Geography and the question of "relevance", Area 3 (2), 65-68.

Clifford, N., 2002: The future of geography: when the whole is less than the sum of its parts, Geoforum 33 (4), 431-436.

Cooper, S., 1966: Theoretical geography, applied geography and planning, Professional Geographer 18 (1), 1-2.

Coppock, J.T., 1974: Geography and public policy: challenges, opportunities and implications, Transactions of the Institute of British Geographers 63, 1-16.

Dickenson, J., Clarke, C. 1972: Relevance and the "newest geography", Area 4 (1), 25-27.

Folke, S., 1972: Why a radical geography must be Marxist, Antipode 4 (2), 13-18.

Frazier, J.W., 1982: Applied Geography: Selected Perspectives, Prentice Hall, Englewood Cliffs.

Hart, J.F., 1989: Why applied geography?, in: Applied Geography: Issues, Questions and Concerns (ed. Kenzer, M.), Kluwer, Dordrecht, 15-22.

Herbertson, A.J., 1899: Report on the Teaching of Applied Geography, Unpublished Report to the Council of the Manchester Geographical Society.

Hills, J., 2010: An Anatomy of Economic Inequality in the UK: Report of the National Enquiry Panel, Government Equalities Office, London.

Hornbeck, D., 1989: Working both sides of the street: academic and business, in: Applied Geography: Issues, Questions and Concerns (ed. Kenzer, M.), Kluwer, Dordrecht, 165-172.

Kenzer, M. (ed.), 1989: Applied Geography: Issues, Questions and Concerns, Kluwer, Dordrecht.

Kraushaar, R., 1979: Pragmatic radicalism, International Journal of Urban and Regional Research 3 (1), 61-80.

Lansley, S., Mack, J., 1991: Breadline Britain in the 1990s, Harper Collins, London.

Lees, L., 2003: Policy (re)turns: gentrification research and urban policy - urban policy and gentrification research, Environment and Planning A 35 (4), 571-574.

Martin, R., 2001: Geography and public policy: the case of the missing agenda, Progress in Human Geography 25 (2), 189-210.

Massey, D., 2001: Geography on the agenda, Progress in Human Geography 25 (1), 5-17.

Merrifield, A., Swyngedouw, E., 1996: The Urbanization of Injustice, Lawrence and Wishart, London.

Murphy, A., 2006: Enhancing geography's role in public debate, Annals of the Association of American Geographers $96(1), 1-13$.

Pacione, M., 1982: Evaluating the quality of the residential environment in a deprived council estate, Geoforum $13(1), 45-55$.

Pacione, M., 1986a: The changing pattern of deprivation in Glasgow, Scottish Geographical Magazine 102 (2), 97-109.

Pacione, M., (1986b) Quality of life in Glasgow - an applied geographical analysis, Environment and Planning A 18 (11), 1499-1520.

Pacione, M., 1987: Multiple deprivation and public policy in Scottish cities: an overview, Urban Geography $8(6), 550-576$.

Pacione, M., 1989a: Access to urban services: the case of secondary schools in Glasgow, Scottish Geographical Magazine 105 (1), 12-18. 
Pacione, M., 1989b: The urban crisis - poverty and deprivation in the Scottish city, Scottish Geographical Magazine 105 (2), 101-115.

Pacione, M., 1990a: What about people? - A critical analysis of urban policy in the United Kingdom, Geography 75 (3), 193-202.

Pacione, M., 1990b: Urban Liveability: A Review, Urban Geography 11 (1), 1-30.

Pacione, M., 1993: The geography of the urban crisis: some evidence from Glasgow, Scottish Geographical Magazine 109 (2), 87-95.

Pacione, M., 1995a: The Geography of Multiple Deprivation in Scotland, Applied Geography 15 (2), 115-133.

Pacione, M., 1995b: The Geography of the New Underclass, Journal of the Scottish Association of Geography Teachers 25, 78-84.

Pacione, M., 1995c: The Geography of Multiple Deprivation in the Clydeside Conurbation, Tijdschrift voor Economische en Sociale Geographie 86 (5), 407-425.

Pacione, M., 1997: The geography of educational disadvantage in Glasgow, Applied Geography 17 (3), 169-192.

Pacione, M. (ed.), 1999: Applied Geography: Principles and Practice, Routledge, London.

Pacione, M., 2003: Quality of life research in urban geography, Urban Geography 24 (4), 314-339.

Pacione, M., 2004a: The Principles and Practice of Applied Geography, in: Applied Geography: A World Perspective (eds. Gibson, L., Bailly, A.), Kluwer Academic Publishers, Dordrecht, 23-45.

Pacione, M., 2004b: Environments of disadvantage - the geography of persistent poverty in Glasgow, Scottish Geographical Journal 120 (1/2), 117-13.

Pacione, M., 2004c: What Constitutes a Healthy Living Environment? A Policy Oriented Perspective on the Health Significance of the Residential Environment, in: Housing and Health, (eds. Bonnefoy, X., Rusticali, F.), World Health Organisation, Bonn, 46-54.

Pacione, M., 2005: Quality of life research in urban geography, in: Urban Geography in America, 1950-2000 (eds. Berry, B., Wheeler, J.), Routledge, New York, 239-264.

Pacione, M., 2009: Urban Geography: A Global Perspective, Routledge, London.

Palm, R., Brazel, A., 1992: Applications of geographic concepts and methods, in: Geographies Inner Worlds (eds. Abler, R., Marcus, M., Olsson, J.), Rutgers University Press, New Brunswick, 342-362.

Prince, H., 1971: Questions of social relevance, Area 3 (3), 150-153.

Sant, M., 1982: Applied Geography: Practice, Problems and Prospects, Longman, London.

Smith, D.M., 1971: Radical geography - the next revolution?, Area 3 (3), 153-157.

Taylor, P., 1985: The value of a geographical perspective, in: The Future of Geography (ed. Johnston, R.J), Methuen, London, 92-110.

Received (Primljeno): 2010 - $11-05$

Accepted (Prihvaćeno): $2011-04-01$

\author{
Professor Michael Pacione, \\ MA PhD DSc FRSGS \\ Chair of Geography \\ University of Strathclyde \\ Glasgow \\ G1 1XH \\ United Kingdom \\ m.pacione@strath.ac.uk
}

